\title{
On Are we all postracial yet?
}

\section{Gavan Titley}

To cite this article: Gavan Titley (2016) On Are we all postracial yet?, Ethnic and Racial Studies, 39:13, 2269-2277, DOI: 10.1080/01419870.2016.1202434

To link to this article: https://doi.org/10.1080/01419870.2016.1202434

\section{央 Published online: 15 Jul 2016.}

Submit your article to this journal $\widetilde{ }$

Џll Article views: 727

View Crossmark data $\nearrow$

47 Citing articles: 3 View citing articles 준 


\title{
On Are we all postracial yet?
}

\author{
Gavan Titley
}

Department of Media Studies, National University of Ireland, Co.Kildare, Ireland

\begin{abstract}
If the postracial is a coherent formation, it is produced not by ideological lockstep but by distributed affinities and relations in a transnational space of interconnection and exchange. The neoliberal erasure of '... the structural conditions of racial reproduction and racist articulation' (34) and the clouding of the historicity of racisms produces postraciality as 'the illusion that the dream of the nonracial has already been realized' (180). This illusion is familiar in writing on the postracial that focuses on the denial - be it through the averted gaze of 'color-blindness', or the official state prohibition of racism, or the triumphalism of strategic declarations of the 'end of racism' - of enduring racialized inequality. Goldberg's advance is to explore how the illusion has become increasingly weaponized; that far from signalling the end of race, it represents an emergent 'neo-raciality, racism's extension if not resurrection' (24).
\end{abstract}

ARTICLE HISTORY Received 5 May 2016; Accepted 9 June 2016

KEYWORDS Racism; race; Europe; digital media; borders; postracialism

The titular question of David Theo Goldberg's incisive and critically important essay suggests multiple valences of public address, or, to put it another way, it immediately invites us to speculate as to who, in a conjuncture of spectacular dehumanization, would pose the question in this form. One voice references the confidence of a certain type of sweeping sociological survey, perhaps eager to convert a sensitizing concept to a definitive claim about the contemporary achievement of a postracial condition. The 'we all' formulation marks it out then undermines it, evoking not only the conceit of academic views from nowhere but also the fidelity of such positions to the 'evaporated transparency' of whiteness; 'the man without racial qualities', the 'not quite absolute arbiter of power', who is just asking a question (125-127). The 'yet' suggests another mode of destabilizing postracial ventriloquism. Inflected with impatience, it mimics the form of the Internet news 'hot take' - 'how could you not be postracial yet?' 'Ten reasons we're all postracial now' - to animate an assumption as pronounced in public debate as in social sciences, that it is mainly those who insist on talking about race that keep the concept alive. 
These inferences are mine, of course, but this intimation of polyvocality is important to the force of the book's central and compelling argument. If the postracial is a coherent formation, it is produced not by ideological lock-step but by distributed affinities and relations in a transnational space of interconnection and exchange. From right to left and in between and beyond, the neoliberal erasure of ' ... the structural conditions of racial reproduction and racist articulation' (34) and the clouding of the historicity of racisms produces postraciality as 'the illusion that the dream of the nonracial has already been realized' (180). This illusion is familiar in writing on the postracial that focuses on the denial - be it through the steadily averted gaze of 'color-blindness', or the official state prohibition of racism, or the triumphalism of strategic declarations of the 'end of racism' - of enduring racialized inequality. Goldberg's advance is to explore how the illusion has become increasingly weaponized; that far from signalling the end of race or even broad acceptance of the illusion of the end of race, it represents an emergent 'neo-raciality, racism's extension if not resurrection' (24). This turn to the force of postraciality demands an answer to the question as to what and who the postracial is for, '... what racial work is the postracial doing, what racist expression is it enabling, legitimating, rationalizing?' (4).

In recent scholarship, much of it taking the election of Barack Obama as a critical threshold, postracialism is predominantly understood in two deeply antagonistic ways, as the motivated ideological denial of racism's enduring sociality, or post-race as an anti-racist ideal, whereby 'post-racialism attempts to develop an anti-race anti-racism capable of imagining and bringing into being a world where the pernicious hierarchies of race no longer feature' (Paul 2014, 705). In Brett St Louis's contribution to Murji and Solomos's edited Theories of Race and Ethnicity - the subject of a previous Ethnic and Racial Studies symposium Vol. 39 No. 32016 - the meaning of the 'postracial' '... can be read on a spectrum ranging from signaling a decisive break to being indicative of an unfinished and uneven process' $(2015,115)$. Surveying a sample of the endless parade of public figures seeking their fifteen minutes through declarations of a 'decisive break', St Louis synthesizes these politically diverse interventions as contributions to the 'fiction' of an 'actually existing post-racial society', a fiction designed to erase and silence realities of racist discrimination, surveillance, stratification and inequality.

Yet - and perhaps as a result of confronting such overlapping and insistent post-race projections as colour-blindness, culturalist integrationism, and neoliberal individuation - St Louis is surely right to underline how this focus on postracialism as illusion and denial has led to a comparative neglect of traditions of anti-race thinking and, as Valluvan and Kapoor put it in their discussion of St Louis' essay in the previous symposium, a lack of attention to how ' ... we might work with the post-race ideal while simultaneously unpacking its proximity to different formations of both residual and contemporary racisms' 
$(2016,377)$. There is much to agree with here, but my focus is on positioning Goldberg's conceptualization on St Louis's spectrum, or rather, in its insistence on the racial work of the postracial, on how it reshapes that continuum. 'Racial dismissal', in Goldberg's treatment, cannot be recalled to specific ideologues, nor framed solely as 'empty gestures' aimed at eliding persistent and enduring racial inequalities and injustices. Rather, denial and dismissal are diffused and generalized, yet, in being structurally organized and discursively sedimented, so deeply articulated as to cohere as an enabling condition of intensified raciality. Thus his own answer to the book's titular question reshapes the spectrum of meanings of the 'postracial' not by adding a third organizing understanding to sit uneasily under the same rubric, but by extending it as a politically and socially productive modality of racist structuration and articulation:

The answer will surprise. We indeed are all postracial already. Only not in the conventional sense the question presupposes. It should be obvious from the evidence provided that socio-structurally we remain very much bound by race. So we are hardly postracial in any literal sense. Rather, we are all postracial structurally by being drawn into the generalized and now unavoidable social logic of postraciality. (Valluvan and Kapoor 2016, 113)

What, then, does this unavoidable social logic look like? In the space available, I will concentrate on two brief examples.A recurring argument in this elaboration of the generativity of the postracial is the ways in which explicit and blatant racist expression are renewed and extended by the purging of racial characterization and reference in 'postracially committed states'. This purging does racial work not only by refusing the enduring and shifting sociality of race, but also by dehistoricizing racist articulation in ways that ' ... dissolve(s) the stain of the racial, rendering it largely invisible, erasing the referential chains linking exterminating missions to any signs of explicit raciality' (p. 48). I was struck when reading this book by just how frequently this argument as to postracialism's 'neo-raciality' played out in everyday public incidents and media events, as if a stream of protagonists had mistaken Goldberg's essay for a handbook rather than critique.

Step forward Laurence Rossignol, France's minister for women's rights and a founding member of SOS Racisme, who objected to innovations in Islamic fashion by riffing on radio in March 2016 that, 'There are women that have chosen (to wear headscarves), there were also American nègres who were for slavery'. ${ }^{1}$ Despite intensive mobilization calling for her resignation, Rossignol did not even offer a standard postracial apology for any 'perceived' insult, but insisted instead that her use of the word nègres - helpfully and tellingly translated in Anglophone media as 'negro' rather than the more plausible if still inaccurate 'N-word' (see Younis 2016) - was no more than an accurate, periodizing reference to Montesquieu's abolitionist writings. 
Rossignol's dialectical insult is almost too perfect an illustration of Goldberg's argument that racisms are relationally structured (107), but the fact that it is possible without political cost - that the airily conjured 'complicity' of those racialized in a system of hereditary chattel slavery can be traduced to further the contemporary racial fixation of the French state and political class on Muslim women as either incapable of or willfully resistant to autonomy - is equally significant. Rossignol's comments belong to a familiar discursive-political genre of performative taboo-breaking and truth-telling composed of ephemeral scandals, strategized media spectacles and relentlessly predictable book-events - such as Thilo Sarrazin (2010) and Éric Zemmour's (2014) respective diagnoses of German and French national suicide - that recuperate racial lexicons and logics through a postracial gambit: in societies after race, the way in which populations and identities are marked out as suspicious, as problems to be contained, intervened in or disposed of, are simply something other than racism. Where the 'referential chain' has been broken, all rhetorical shackles can be cast off, and the 'dog whistle' can now bang out its back catalogue of unconstrained and adapted anthems on a frequency far closer to you.

This may be an established strategy, and one with a clear genealogy in the hegemonic designs of the European New Right, but the force of Goldberg's argument is to examine the consequences in a broader postracial condition that '... employs these variously instrumentalizing racial animations while denying that they add up to racism. Or denying indeed that racial characterization is being invoked' (87). In readings of the postracial as what Brett St Louis termed the 'fiction of the actually existing post-racial society' $(2015,146)$, the problem with incidents such as this is that they are at best epiphenomenal, too easily passed off as aberrant expressions, clumsy and anachronistic utterances that, once apologized for (that is, for any offence that may have been taken), serve as a ritual confirmation of the broadly attained racelessness of the contemporary polity. The media event, in this reading, is a ritual of public reconstruction which serves to deepen racism's deniability, to further mystify the 'deep structural life of racism' under, say, neoliberal conditions (Davis 2008, 4). Yet, as the attempt by activists in France to leverage Rossignol's comments into a wider mobilization against state racism ${ }^{2}$ suggests, what is often at stake in these incidents is not (solely) the utterance but the political conditions of its possibility, and the performativity of its effects. 'Irruptive racisms', as Goldberg argues, appear anomalous and discrete but they cannot, as outbursts in public discourse often are, be dismissed as epiphenomenal. Instead, they frequently provide indicators as to how the terms of racist articulation are being re-worked, for ' ... the paradox of postraciality is that its racial erasures are coterminous with new intensities in racist expression' (p. 127). 
My second example is to think about the contemporary border crisis in Europe in these terms of erasure and (re)new(ed) intensities. Significant mediated public attention has been focused on 'racist responses' to refugee movement. Torch-carrying far-right mobilizations; Danish flirtations with the echoes of Holocaust accumulation; Hungarian fusions of Ottoman-opposing nostalgia with the memes of networked Islamophobia: these reverse backwards across the threshold for recognition as racism, irruptions that most symbolically or affectively recall '... past events that have been sanctioned for identification as racist' (Lentin 2016). The critical contemporary problem, Goldberg argues, is getting to grips with the conditions that enable these back-tothe-future irruptions - not just racism without race or racists but 'racisms without racism', the production of 'unraced' raciality as:

... a (if not the) principal modality for defining and identifying the threatening within and without; the sub-human or sub-standard human, the beastly, inferiorized, the deviant, the degenerate, the immature, even the (potentially) ill from who (from which) as Foucault reveals, society must be defended. Scrubbed of its pernicious historical resonances, the racial is sublimated within the intersection of more socially agreeable references. (p. 117)

This 'unraced raciality' hides in plain sight in the publicly foregrounded technocratic negotiations of mass deportations and population swaps; in the designation of the internal colony of Greece as a prophylactic border zone; in the extension of racial profiling through extensive networked border practices in metropolitan spaces and transit zones; through the rendering, after midnight on 3 April 2016, of most Syrians as excess, even as the exceptionalization of Syrians has been mustered to delegitimize those fleeing other, older wars and regional destabilization; through a marking out of disposability in the waters of the Mediterranean as nothing more than 'not creating a migration incentive', through the denial of basic conditions of day-to-day dignity in camps, warehouses and halting sites. And, as the Turkish army deploys lethal force against refugees, the extension of racially produced death not just through willful negligence but through an intensification of what Nicholas De Genova terms 'The Border Spectacle', an intensification in direct response to the 'haunting of Europe's borders' by an '... appalling proliferation of (almost exclusively non-European/non-white) migrant and refugee deaths and other forms of structural violence and generalised suffering' (2016). And, all of this furthered through the 'socially agreeable reference' to humanitarianism, development, 'societal resilience' and human rights. If racisms, as Goldberg argues in his concluding chapter, always involve narcissistic selfregard, the spectacle of the European Union contending that the only significant human rights issue under consideration in this relentless drive to mark out disposable lives is whether Turkey could be relied on to respect 'our values', attests to a narcissism without borders. 
What is critical, I think, about this contrapuntal dynamic of erasure and extension is that it brings into focus the challenge for contemporary antiracisms to not only oppose recognizable forms of racist expression but to develop 'cultures of engaged critique of the histories of racist exclusion and humiliation' such that they (we) can oppose the structural conditions that enable forms of racist reproduction and configuration. That is, forms whose particular valence is that they thrive through insistence on the nonracial, or, more accurately, the 'social magic' of alchemizing 'racism into nonracialism' (p. 94). It is clear from Goldberg's reference to the importance of coalitional antiracisms 'from below' - in his concluding discussion of the need for an 'ecological' anti-racism that addresses the 'larger landscape of structural conditions supporting and enabling the reproduction of racist arrangements and expression' - that postracialism fashions a particularly pressing iteration of the comparative critical neglect of antiracist movements in the field of research. In the opposition, say, to the detention, deportation, surveillance of people who migrate, or the multivalent production of Muslims and Muslim-looking people as a problem population, what responses to the alchemy of non-racialism are being collectively produced and negotiated, and what affirming visions anchor them and emerge from them?

'Race today is supposed to be a thing of the past. But all we do, seemingly, is talk about it'. From page one, talk, or more precisely, mediated talk, is present in Goldberg's elucidation of postracialism's generative 'work', and it is not surprising that 'social media' feature as a key locus of this mediated talk, as they do in Miri Song's recent elaboration of a 'culture of racial equivalence' (2013). Where Song focuses on Twitter's deliberative limitations, Goldberg turns frequently to Facebook's irruptive affordances: inhabiting an ambivalent location between public and private, blatantly racist Facebook posts by celebrities and ordinary users continually drive debate as to what, exactly, now constitutes racism, circulating through networked publics but continually recalled to questions of intention - 'it was only a joke' - or context, 'the joke was coded for my friends, not for a wider public'.

As a scholar located in Media and Communications, the imbrication of digital media in the 'work' of the postracial is of significant interest, but I think the situated dynamics of connective media, how they mediate and mediatize, requires more attention. This is not a criticism of this book, which is clearly a particular form of intervention, and it is also the case that race and racism receive very limited contemporary consideration in Media and Communications (see Daniels 2012; Titley 2014). Rather, I want to suggest, in the spirit of Goldberg's argument, a greater integration of what are often considered merely as 'bolt on' techno-socialities to the emerging sociality of postracialism. Briefly, here are three dimensions for future consideration. 
The first is the question of noise. The denial in the postracial has frequently been associated with silencing, from Dan-Ain Davis' idea of 'muted racism' which 'forces claims of racism into silence' $(2007,349)$ - to Goldberg's allusive lexicon of 'evaporation' and 'quieting' in The Threat of Race (2009). Connective media, given their formal and networked demand for user-participation and corporate imperative of content generation, depend, as Nick Couldry has argued, on 'hugely increased incitements to discourse'; the ephemeral invitation to react, share, signal or comment $(2012,126)$. This incitement can act to force claims of racism into silence, but through amplification and volubility. At the intersection of postracial denial and digital incitement, the very mention of race serves as an invitation to disprove its salience, the mention of racism as an invitation to refute its relevance.

The participatory platforms and discursive forms of connective media amplify the dynamics of denial - as many writers of colour have experienced in an economy of interactivity, to speak publicly about racism is to provide a reliable incitement to discourse, an affective trigger in the 'intuitive scanning' practiced in 'comment cultures' (Lovink 2011, 57). It is to be immediately integrated into an intensive process of delineation, deflection and denial, a contest over who gets to define racism, when 'everyone' gets to speak about it. I have recently tried to conceptualize this as the 'debatability' of racism (Titley 2016), by which I do not mean that the experience of racism is open to debate, but rather as to how the experience of racism and the operations of structural racism can be denied not only through silencing, but through noise, not just through a lack of attention to racism, but through an excess of particular kinds of attention.

The second is the question of fascination. Connective media are often still treated as 'new' media, and in public discussions of racism, as uncivil spaces where 'hate speech' and racist sub-cultures flourish. However, 'old' and 'new' media are, by this stage, analytically empty concepts. As Andrew Chadwick has argued, the integration of connective media with 'legacy' media produces a 'hybrid media system' of competing and merging media logics that shape the production of news, mediation of public opinion, flow of political information, and contest of symbolic power (2013). The increasing integration of social media material into expansive digital spaces of news production and comment is one result of this, and in this media context debatability also has a political economic dimension. Media fascination with racism as a driver of spectacle, controversy and comment is increasingly dependent on social media material as primary source.

Take for example how the trend towards 'content curation', particular in US-based sites, has led to the development of a genre of meta-commentary on what counts as racism: 'This viral video shows how racism in real in Australia'; 'This tweet exemplifies how white feminism doesn't get racism'; 'The hashtag that led to the response to online racism'. It is this same content 
prerogative that drives the 'Facebook scandal' dynamic that recurs in Goldberg's book, and it now informs an established media tactic of politicians of the electoral radical right, who can post 'red meat' for certain followers, safe in the knowledge that journalists are following them and anti-racist activists waiting to screengrab their provocations, while appealing to the interpretative horizon of the private and contextual when they ensuing publicity tips over into the risk of alienating other constituencies.

The third is the question of bricolage. In his essay 'The remainders of race', Ash Amin offers the metaphor of 'racial debris' as a way of understanding the re-articulation of racial references, images and logics held to be 'past' but which are re-articulated under particular social and political conditions, where ' ... the potentiality of accumulated racial debris, variegated and dormant from different eras, (is) ready to be instantiated in unknown ways' $(2010,5)$. Transnational media spaces provide extensive opportunities to sift and assemble debris, debris that can be drawn from an extended archive and repertoire of racial conceptions and associations given that the 'visual turn and the technological turn are converging as images migrate and proliferate onto digital platforms' (Nakamura and Chow-White 2012, 5). The connective and 'spreadable' affordances of digital media, and such practices as remix, mash-up and parody, drive cultural production, and these syncretic and diffusive dynamics provide media users of all kinds with extended and volatile repertoires of racial reference and suggestion. Postraciality, as Goldberg argues, ' ... amounts to a general social ecology within which race and racisms are supposedly outmoded but where in fact racist expression has gone viral' (106). This ecology is in part transnational and intensely mediated, and the impact of digital bricolage, of assemblages of debris, of the accumulation of posts and memes and links that cannot be recalled to a foundational racism but that shape and provoke racist irruptions, seems to me to be emerging as a field where the racial work of the postracial is being unfolded.

\section{Notes}

1. 'Il y a des femmes qui choisissent, il y avait aussi des nègres afric ... des nègres américains qui étaient pour l'esclavage'.

2. See http://www.islamophobie.net/articles/2016/03/31/grande-operation-affairerossignol.

\section{Disclosure statement}

No potential conflict of interest was reported by the author.

\section{References}

Amin, A. 2010. "The Remainders of Race." Theory Culture \& Society 27 (1): 1-23. Chadwick, A. 2013. The Hybrid Media System. Oxford: OUP. 
Couldry, N. 2012. Media, Society, World: Social Theory and Digital Media. Cambridge: Polity.

Daniels, J. 2012. "Race and Racism in Internet Studies: A Review and Critique." New Media \& Society 15 (5): 696-719.

Davis, Dana-Ain. 2007. "Narrating the Mute: Racializing and Racism in a Neoliberal Moment." Souls 9 (4): 346-360.

Davis, A. 2008. "Recognizing Racism in the Neoliberal Era." Vice Chancellor's Oration at Murdoch University. http://www.truth-out.org/opinion/item/16188-recognizingracism-in-the-era-of-neoliberalism.

De Genova, N. 2016. "The 'Crisis' of the European Border Regime: Towards a Marxist Theory of Borders." International Socialism, Issue 150. http://isj.org.uk/the-crisis-ofthe-european-border-regime-towards-a-marxist-theory-of-borders/.

Goldberg, D. T. 2009. The Threat of Race. Cambridge: Polity Press.

Goldberg, D. T. 2015. Are We All Postracial Yet? Cambridge: Polity Press.

Lentin, A. 2016. "The Lure of 'Frozen' Racism." The Occupied Times, March 31. https:// theoccupiedtimes.org/?p=14225.

Lovink, G. 2011. Networks without a Cause: A Critique of Social Media. Cambridge: Polity. Murji, K., and J. Solomos, eds. 2015. Theories of Race and Ethnicity: Contemporary Debates and Perspectives. Cambridge: CUP.

Nakamura, L., and Chow-White, P. A. 2012. "Introduction: Race and Digital Technology: Code, the Color Line and the Information Societies". In Race After the Internet, edited by L. Nakamura and P. A. Chow-White, 1-18. London: Routledge.

Paul, J. 2014. "Post-Racial Futures: Imagining Post-Racialist Anti-Racism(s)." Ethnic \& Racial Studies, 37 (4): 702-718.

Sarrazin, T. 2010. Deutschland schafft sich ab. Berlin: Deutsche Verlags-Anstalt.

Song, M. 2013. "Challenging a Culture of Racial Equivalence." MIM Working Papers Series 13: 5.

St Louis, B. 2015. "Can Race be Eradicated? The Post-Racial Problematic." In Murji \& Solomos op.cit.

Titley, G. 2014. "No Apologies for Cross-Posting: European Trans-Media Space and the Digital Circuitries of Racism." Crossings: Journal of Migration and Culture 5 (1): 41-55.

Titley, G. 2016. "The Debatability of Racism." https://raster.fi/2016/02/17/thedebatability-of-racism-networked-participative-media-and-postracialism/.

Valluvan, S., and N. Kapoor. 2016. "Notes on Theorizing Racism and Other Things." Ethnic and Racial Studies 39 (3): 375-382.

Younis, M. 2016. "N is for Muslim." London Review of Books Blog. http://www.lrb.co.uk/ blog/2016/04/01/musab-younis/n-is-for-muslim/.

Zemmour, É. 2014. Le Suicide français. Paris: Albin Michel. 